\title{
SUPERVISI AKADEMIK KEPALA SEKOLAH TERHADAP KINERJA GURU PENDIDIKAN AGAMA ISLAM DI SEKOLAH DASAR NEGERI 79 KOTA BENGKULU
}

\section{ACADEMIC SUPERVISION OF HEADMASTER ON TEACHER PERFORMANCE OF ISLAMIC RELIGIOUS IN ELEMENTARY SCHOOL 79 BENGKULU CITY}

\author{
A. Suradi \\ Fakultas Tarbiyah dan Tadris IAIN Bengkulu \\ Jl. Raden Fatah Pagar Dewa kota Bengkulu \\ suradi@iainbengkulu.ac.id
}

\begin{abstract}
Abstrak
Penelitian ini bertujuan untuk mengetahui supervisi akademik kepala sekolah pada kinerja guru pendidikan agama Islam di Sekolah Dasar Negeri 79 Kota Bengkulu serta faktor-faktor yang mempengaruhinya. Jenis penelitian ini adalah penelitian lapangan dengan pendekatan kualitatif. Dari hasil penelitian terungkap bahwa, supervisi akademik yang dilaksanakan oleh kepala sekolah, yaitu: supervisi akademik berkaitan dengan perencanaan pembelajaran terdiri dari pembimbingan dalam merumuskan tujuan pembelajaran, supervisi akademik pada pelaksanaan pembelajaran, meliputi: pemberian contoh dalam membuka pembelajaran, pemberian contoh dalam menyajikan materi pembelajaran, serta supervisi akademik pada evaluasi pembelajaran, meliputi: pembimbingan dalam menyusun perangkat penilaian pembelajaran. Sedangkan faktor-faktor yang mempengaruhi pelaksanaan supervisi akademik, yaitu: faktor pendukungnya, yakni guru yang menjadi sasaran supervisi kepala sekolah bersikap koperatif dan terbuka terhadap proses supervisi yang dilakukan oleh pengawas. Faktor penghambat pelaksanaan supervisi kepala sekolah dalam upaya peningkatan kinerja guru Pendidikan Agama Islam, yakni sempitnya alokasi waktu untuk pelaksanaan pembelajaran PAI di sekolah dasar.
\end{abstract}

Kata Kunci: Supervisi, Kepala Sekolah, Kinerja Guru

\begin{abstract}
This study aims to determine the principal academic supervision on the performance of Islamic religious education teachers at State Elementary School of 79 Bengkulu City and the factors that influence it. This type of research is field research with qualitative approach. From the research results revealed that, academic supervision carried out by the principal, namely: academic supervision related to learning planning consists of coaching in formulating learning objectives, academic supervision on the implementation of learning, including: giving examples in opening learning, giving examples in presenting learning materials, as well as academic supervision on the evaluation of learning, including: coaching in preparing the assessment of learning tools. While the factors that influence the implementation of academic supervision, namely: the supporting factor, namely the teacher who became the target of supervision of the principal to be cooperative and open to the supervision process conducted by the supervisor. Inhibiting factor of principal supervision in improving teacher performance, is the limited time allocation for the implementation of PAI learning in elementary school.
\end{abstract}

Keyword: Supervision, Headmaster, Teacher, Performance

\section{Pendahuluan}

Keberhasilan penyelenggaraan pendidikan sangat ditentukan oleh kemampuan kepala sekolah dalam mengelola semua sumber daya yang ada di sekolah. Hal tersebut 
sesuai dengan yang dikemukakan Mulyasa (2004: 24), bahwa kepala sekolah merupakan salah satu komponen pendidikan yang paling berperan dalam meningkatkan kualitas pendidikan. Dari pendapat tersebut, jelas bahwa yang menjadi penentu keberhasilan suatu sekolah terletak pada kemampuan kepala sekolah dalam melaksanakan tugas-tugasnya. Tugas utama kepala sekolah sebagai pemimpin sekolah adalah menciptakan situasi pembelajaran yang kondusif sehingga para guru dan siswa dapat melaksanakan kegiatan pembelajaran dengan baik di lingkungan sekolahnya.

Salah satu program yang dapat diselenggarakan untuk meningkatkan mutu pembelajaran adalah pelaksanaan bantuan kepada guru atau yang lebih dikenal dengan istilah supervisi. Kepala sekolah sebagai pemimpin pendidikan di sekolah mempunyai tugas di bidang supervisi. Secara tegas, Dirjen Peningkatan Mutu Pendidik dan Tenaga Kependidikan Kemendikbud, menyebutkan bahwa tugas di bidang supervisi merupakan tugas kepala sekolah yang berkaitan dengan pembinaan guru untuk perbaikan pengajaran. Supervisi merupakan suatu usaha memberikan bantuan kepada guru untuk memperbaiki atau meningkatkan proses dan situasi pembelajaran. Sasaran akhir dari kegiatan supervisi adalah meningkatkan hasil belajar siswa (Departemen Pendidikan Nasional, 2007: 4).

Berdasarkan uraian tersebut, dapat dilihat bahwa dalam usaha untuk memperbaiki dan meningkatkan proses pembelajaran yang dilakukan oleh guru, kepala sekolah bertugas menyelenggarakan serta melaksanakan kegiatan supervisi. Tugas ini cukup penting karena melalui peran supervisor, kepala sekolah dapat memberi bantuan, bimbingan, ataupun layanan kepada guru dalam menjalankan tugas ataupun dalam memecahkan permasalahan yang dihadapi pada saat proses pembelajaran.

Kinerja guru Pendidikan Agama Islam merupakan suatu hasil kerja yang dicapai seseorang guru agama dalam melaksanakan tugas-tugas yang dibebankan kepadanya yang didasarkan atas kecakapan, pengalaman, dan kesungguhan serta waktu. Kinerja guru Pendidikan Agama Islam dapat dilihat saat dia melaksanakan interaksi pembelajaran di kelas termasuk persiapannya baik dalam bentuk program maupun evaluasi mengajarnya.

Dari hasil penelitian awal yang peneliti lakukan di SD Negeri 79 Kota Bengkulu melalui wawancara, didapatkan permasalahan yang terkait pelaksanaan supervisi akademik kepala sekolah. Permasalahan itu adalah pelaksanaan supervisi akademik yang dilaksakan oleh kepala sekolah masih kurang maksimal. Hal tersebut dikarenakan supervisi kepala sekolah didominasi soal pekerjaan administratif dibandingkan dengan melakukan supervisi terhadap kegiatan akademik di sekolah. Dengan hal tersebut berdampak pada guru Pendidikan Agama Islam yang kurang mendapatkan bimbingan dari kepala sekolah.

Hasil wawancara peneliti, disebutkan bahwa kegiatan supervisi akademik oleh kepala sekolah tidak teratur dan tidak terjadwal sehingga tidak bisa diprediksi berapa kali kepala sekolah menyupervisi guru. Kegiatan supervisi akademik tersebut terkadang dilaksanakan satu kali pada tiap semester. Oleh karena itu, dapat dikatakan bahwa pelaksanaan supervisi akademik yang dilakukan oleh kepala sekolah kepada guru Pendidikan Agama Islam dalam melaksanakan proses pembelajaran di SD Negeri 79 Kota Bengkulu kurang maksimal.

Berdasarkan hasil wawancara dengan kepala sekolah SD Negeri 79 Kota Bengkulu, peneliti mendapatkan informasi bahwa kegiatan supervisi akademik oleh kepala sekolah pada pelaksanaan pembelajaran yang dilakukan oleh guru Pendidikan Agama Islam belum dilakukan secara rutin. Kepala sekolah tidak mempunyai banyak 
waktu untuk melakukan supervisi akademik pada pelaksanaan pembelajaran karena kesibukan dan banyaknya juga aktivitasnya di luar.

Permasalahan lain yang muncul terkait dengan kegiatan supervisi akademik oleh kepala sekolah, yaitu guru Pendidikan Agama Islam di SD Negeri 79 Kota Bengkulu mengungkapkan bahwa belum mendapatkan bimbingan dari kepala sekolah untuk meningkatkan kemampuannya dalam mengelola pembelajaran sebagai tindak lanjut dari pelaksanaan supervisi akademik oleh kepala sekolah. Dapat dikatakan bahwa belum semua guru mendapatkan feedback (umpan balik) dari hasil pelaksanaan supervisi akademik sehingga berpengaruh pada kinerjanya.

Dari hasil studi awal bahwa kinerja guru Pendidikan Agama Islam dalam pembelajaran masih menunjukkan belum optimal, karena terlihat hasil kerja yang dicapai guru Pendidikan Agama Islam dalam melaksanakan tugas-tugas yang dibebankan kepadanya belum didasarkan atas kecakapan, pengalaman, dan kesungguhan serta waktu.

Berdasarkan uraian di atas, supervisi akademik merupakan tugas yang harus dilaksanakan kepala sekolah dalam meningkatkan kinerja guru Pendidikan Agama Islam. Oleh karena itu peneliti mencoba untuk mengadakan penelitian tentang supervisi akademik oleh kepala sekolah dalam peningkatan kinerja guru Pendidikan Agama Islam di Sekolah Dasar Negeri 79 Kota Bengkulu.

\section{Metode Penelitian}

Penelitian ini merupakan jenis penelitian lapangan (field research) dan peneliti menggunakan pendekatan deskriptif kualitatif, baik berupa tulisan atau ungkapan yang diperoleh langsung dari lapangan atau wilayah penelitian (Komaruddin dan Yooke Tjuparmah, 2000: 55). Penelitian ini merupakan penelitian kualitatif, karena data-data yang diperoleh di lapangan adalah berupa uraian kata-kata serta ungkapan secara deskripsi dari hasil wawancara responden dan observasi.

Tujuan penelitian ini adalah untuk menggali dan mengumpulkan data berupa hasil penelitian dan keterangan yang berkaitan dengan penelitian, yaitu pelaksanaan supervisi akademik oleh kepala sekolah dalam meningkatkan kinerja guru Pendidikan Agama Islam di Sekolah Dasar Negeri 79 Kota Bengkulu.

Teknik analisis data yang digunakan adalah teknik deskriptif kualitatif, yaitu teknik analisis yang menggambarkan dan memaparkan dengan bentuk uraian hasil penelitian yang diperoleh langsung dari lapangan yang berkaitan dengan tema penelitian. Teknik analisis ini menggunakan metode deduktif yaitu cara yang dilakukan dengan mengemukakan pikiran atau pendapat untuk mendapatkan suatu pengertian dari pendapat yang umum kemudian diambil pengertian menjadi pendapat yang khusus.

Adapun langkah-langkah peneliti menganalisis hasil penelitian yang diperoleh langsung dari lapangan, yaitu dengan model interaktif Miles dan Huberman sebagaimana dikutip Sugiyono (2008: 252), dengan menggunakan langkah-langkah berikut:

a. Reduksi data (data reduction)

Yaitu merangkum, memilih ha-hal yang pokok, memfokuskan pada hal-hal yang penting, serta dicari tema dan polanya. Dalam hal ini merangkum hasil data penelitian yang didapatkan dari lapangan.

b. Verifikasi data

Yaitu menyajikan dan menginterpretasikan data/fakta di lapangan yang telah diolah lalu dibandingkan dengan ketentuan-ketentuan teoritis dan normatif yang berlaku. 
c. Display Data

Yaitu sekumpulan informasi yang telah tersusun dari hasil reduksi data, kemudian disajikan dalam laporan yang sistematis dan mudah dibaca atau dipahami.

d. Menarik kesimpulan

Yaitu memberikan kesimpulan terhadap hasil penelitian yang didapatkan dari lapangan, dan merupakan jawaban rumusan masalah yang dirumuskan sejak awal dalam penelitian ini.

\section{Deskripsi Konseptual}

\subsection{Supervisi Akademik Kepala Sekolah}

\subsubsection{Fungsi Supervisi Akademik}

Mengacu pada tujuan supervisi akademik, maka perlu diketahui juga fungsi supervisi akademik. Adapun fungsi supervisi menurut Arikunto, ada tiga yaitu:

a. sebagai upaya meningkatkan mutu pembelajaran,

b. sebagai pemicu atau penggerak terjadinya perubahan pada unsur-unsur yang terkait dengan pembelajaran,

c. sebagai kegiatan memimpin dan membimbing (Arikunto, 2009:13).

Menurut Sagala, fungsi supervisi akademik adalah memberikan pelayanan supervisi pengajaran kepada guru untuk menumbuhkan proses pembelajaran yang berkualitas baik, menyenangkan, inovatif dan dapat menjaga keseimbangan pelaksanaan tugas staf mengajar (Sagala, 2009: 106). Selain itu, fungsi supervisi akademik adalah sebagai berikut:

a. Penelitian

Dalam fungsi ini supervisi bertujuan untuk memperoleh gambaran yang jelas dan obyektif tentang situasi pendidikan (khususnya sasaran supervisi akademik) dengan menempuh prosedur: 1) perumusan pokok masalah sebagai fokus penelitian, 2) pengumpulan data, 3) pengolahan data, dan 4) penarikan kesimpulan yang diperlukan untuk perbaikan dan peningkatan.

b. Penilaian

Yaitu dengan mengevaluasi hasil penelitian, sehingga bisa mengetahui apakah situasi pendidikan yang diteliti itu mengalami kemunduran, kemandekan atau kemajuan, memprihatinkan atau menggembirakan.

c. Perbaikan

Yaitu melakukan langkah-langkah: 1) mengidentifikasi aspek-aspek negatif - berupa kekurangan atau kemandegan, 2) mengklasifikasi aspek-aspek negatif - menentukan yang ringan dan yang serius, 3) melakukan perbaikan-perbaikan menurut prioritas, dengan mengacu pada hasil penilaian.

d. Peningkatan

Supervisi berupaya memperhatikan kondisi-kondisi yang telah memuaskan dan bahkan meningkatkannya, karena dilakukan upaya perbaikan melalui proses yang berkesinambungan dan terus menerus (Satori, 2004: 3).

Berdasarkan beberapa pendapat di atas, maka dapat disimpulkan bahwa fungsi supervisi akademik adalah membantu sekolah dalam pemberian layanan pada guru-guru untuk dapat bekerja dengan baik yaitu dengan mampu melaksanakan proses pembelajaran yang berkualitas, menyenangkan, dan inovatif kepada siswa di sekolah. 


\subsubsection{Sasaran Supervisi Akademik}

Arikunto mengemukakan sasaran supervisi ada tiga macam yaitu: pertama, Supervisi akademik, yang menitikberatkan pengamatan supervisor pada masalahmasalah akademik, yaitu hal-hal yang berlangsung dalam lingkungan kegiatan pembelajaran pada waktu siswa sedang dalam proses mempelajari sesuatu, Kedua. Supervisi administrasi, yang menitikberatkan pengamatan supervisor pada aspek-aspek administratif yang berfungsi sebagai pendukung dan mempelancar terlaksananya pembelajaran, Ketiga, Supervisi lembaga yang menebar atau menyebarkan objek pengamatan supervisor pada aspek-aspek yang berada di seantero sekolah (Arikunto, 2009: 33).

Dalam pelaksanaannya kegiatan supervisi akademik diarahkan pada pembinaan dan pengembangan aspek-aspek yang berkaitan dengan proses pembelajaran. Guru merupakan komponen yang terlibat langsung dan bertanggung jawab atas proses pembelajaran di kelas, sehingga yang menjadi fokus atau sasaran utama supervisi akademik adalah yang berkaitan dengan guru.

Prasojo dan Sudiyono menyebutkan bahwa sasaran supervisi akademik adalah guru dalam proses pembelajaran, yang terdiri dari materi pokok dalam proses pembelajaran, penyusunan silabus dan RPP, pemilihan strategi/metode/teknik pembelajaran, penggunaan media dan teknologi informasi dalam pembelajaran, menilai proses dan hasil pembelajaran serta penelitian tindakan kelas (Prasojo dan Sudiyono, 2011: 83). Pelaksanaan supervisi akademik pada seluruh komponen yang harus disupervisi menurut Arikunto, meliputi:

a. Intensitas keterlibatan siswa dalam kegiatan pembelajaran.

b. Perhatian guru kepada siswa yang sedang sibuk belajar, penampilan guru dalam menjelaskan materi pelajaran, keterampilan guru dalam menggunakan alat peraga, ketelitian guru dalam menilai hasil belajar siswa di kelas atau mengoreksi pekerjaan tes.

c. Keluasan dan kedalaman materi yang disajikan di kelas, keruntutan dan urutan penyajian materi, banyaknya dan ketepatan contoh untuk memperkuat konsep, jumlah dan jenis sumber bahan pendukung pokok bahasan yang dibahas di kelas.

d. Ketersediaan alat peraga selama proses pembelajaran berlangsung, ketepatan alat dengan pokok bahasan, benar tidaknya penggunaan alat peraga, keterlibatan siswa dalam menggunakan alat peraga.

e. Pembagian siswa dalam tugas kelompok, penunjukan siswa yang disuruh maju ke papan tulis mengerjakan soal, cara mengatur siswa yang menganggu temannya.

f. Hiasan dinding dalam kelas, kebersihan kelas, ketenangan kelas, kenyamanan udara, ventilasi, pajangan hasil pekerjaan siswa di kelas (Arikunto, 2009: 33).

Berdasarkan uraian di atas, maka dapat disimpulkan bahwa sasaran utama supervisi akademik adalah kemampuan guru dalam melaksanakan proses pembelajaran yang meliputi merencanakan kegiatan pembelajaran, melaksanakan kegiatan pembelajaran, serta menilai atau evaluasi pembelajaran. Dengan demikian diharapkan supervisi akademik dapat memperbaiki dan membantu guru dalam mengatasi permasalahan yang berkaitan dengan pengelolaan pembelajaran.

\subsubsection{Teknik-teknik Supervisi Akademik}

Melaksanakan supervisi akademik dalam rangka perbaikan pembelajaran menjadi tugas kepala sekolah. Untuk dapat melaksanakan supervisi akademik secara efektif, kepala sekolah harus memiliki teknik-teknik supervisi yang tepat dalam melaksanakan 
supervisi. Menurut Prasojo dan Sudiyono (2011), teknik supervisi akademik ada dua macam yaitu teknik supervisi individual dan teknik supervisi kelompok.

a. Teknik Supervisi Individual

1) Kunjungan kelas, merupakan teknik pembinaan guru oleh kepala sekolah untuk mengamati proses pembelajaran di kelas dengan tujuan untuk menolong guru dalam mengatasi permasalahan di kelas.

2) Observasi kelas, merupakan kegiatan mengamati proses pembelajaran secara teliti di kelas dengan tujuan untuk memperoleh data yang objektif terkait dengan aspek-aspek situasi pembelajaran, dan kesulitan-kesulitan guru dalam usaha memperbaiki proses pembelajaran.

3) Pertemuan individual, merupakan suatu pertemuan, percakapan, dialog, dan tukar pikiran antara supervisor dan guru dengan tujuan memberikan kemungkinan pertumbuhan jabatan guru melalui pemecahan kesulitan yang dihadapi, mengembangkan hal mengajar yang lebih baik, memperbaiki segala kelemahan dan kekurangan pada diri guru, dan menghilangkan atau menghindari segala prasangka.

4) Kunjungan antar kelas, adalah guru yang satu berkunjung ke kelas yang lain di sekolah itu sendiri dengan tujuan untuk berbagi pengalaman dalam pembelajaran.

5) Menilai diri sendiri, merupakan penilaian diri yang dilakukan oleh diri sendiri secara objektif. Dengan demikian diperlukan kejujuran diri sendiri.

b. Teknik Supervisi Kelompok

Teknik supervisi kelompok adalah satu cara melaksanakan program supervisi yang ditujukan pada dua orang atau lebih. Guru-guru yang diduga sesuai dengan analisis kebutuhan, memiliki masalah atau kebutuhan atau kelemahan-kelemahan yang sama, dikelompokkan menjadi satu. Pemberian layanan supervisi sesuai dengan permasalahan atau kebutuhan yang mereka hadapi. Ada tiga belas teknik supervisi kelompok, yaitu: kepanitiaan-kepanitiaan, kerja kelompok, laboratorium dan kurikulum, membaca terpimpin, demontrasi pembelajaran, darmawisata, kuliah/studi, diskusi panel, perpustakaan, organisasi profesional, buletin supervisi, pertemuan guru, lokakarya atau konferensi kelompok (Prasojo dan Sudiyono, 2011, 102).

Teknik supervisi kelompok dalam pengertian supervisi secara umum menurut Purwanto, meliputi beberapa kegiatan yang dapat dilakukan antara lain:

1) Mengadakan pertemuan atau rapat (meeting). Seorang kepala sekolah yang baik umumnya menjalankan tugasnya berdasarkan rencana yang telah disusunnya. Adapun yang termasuk dalam perencanaan itu antara lain adalah mengadakan rapatrapat secara periodik dengan guru-guru.

2) Mengadakan diskusi kelompok (group discussions). Diskusi kelompok dapat diadakan dengan membentuk kelompok-kelompok guru bidang studi sejenis. Kelompok-kelompok yang telah terbentuk itu diprogramkan untuk mengadakan pertemuan/diskusi guna membicarakan hal-hal yang berhubungan dengan usaha pengembangan dan peranan proses pembelajaran.

3) Mengadakan penataran-penataran (inservice-training). Teknik supervisi kelompok yang dilakukan melalui penataran-penataran sudah banyak dilakukan, misalnya penataran untuk guru-guru bidang studi tertentu, penataran tentang metodologi pengajaran, dan penataran tentang administrasi pendidikan. Mengingat bahwa penataran-penataran tersebut pada umumya diselenggarakan oleh pusat atau wilayah, maka tugas kepala sekolah adalah mengelola dan membimbing pelaksanaan tindak lanjut (follow-up) dari hasil penataran (Purwanto, 2005: 120-121). 
Berdasarkan beberapa pendapat di atas, maka dapat disimpulkan bahwa teknik supervisi akademik pada umumnya ada dua macam, yaitu teknik supervisi individual dan teknik supervisi kelompok. Tidak satupun di antara teknik-teknik supervisi individual maupun kelompok yang dikemukakan di atas cocok atau dapat diterapkan untuk semua guru di sekolah. Hal tersebut dipengaruhi oleh perbedaan permasalahan yang dihadapi masing-masing guru dan perbedaan karakteristik dari masing-masing guru, oleh karena itu kepala sekolah harus bisa menetapkan teknik-teknik mana yang sekiranya mampu membina keterampilan pembelajaran seorang guru.

\subsection{Pelaksanaan Supervisi Akademik}

Menurut Peraturan Menteri Pendidikan Nasional Nomor 13 Tahun 2007 tentang Standar Kepala Sekolah/Madrasah, dengan jelas ditegaskan bahwa salah satu tugas kepala sekolah adalah melaksanakan supervisi akademik yang meliputi: merencanakan program supervisi akademik dalam rangka peningkatan profesionalisme guru, melaksanakan supervisi akademik terhadap guru dengan menggunakan pendekatan dan teknik supervisi yang tepat, menindaklanjuti hasil supervisi akademik terhadap guru dalam rangka peningkatan profesionalisme guru. Bantuan profesional dari kepala sekolah pada proses pembelajaran tersebut sangat diperlukan oleh guru agar tujuan pembelajaran dapat tercapai. Supervisi akademik oleh kepala sekolah dalam proses pembelajaran, meliputi supervisi akademik pada perencanaan pembelajaran, supervisi akademik pada pelaksanaan pembelajaran, dan supervisi akademik pada evaluasi pembelajaran.

\subsubsection{Supervisi Akademik pada Perencanaan Pembelajaran}

Menurut Burden dan Byrd dalam Alben Ambarita (2006: 73), perencanaan adalah menetapkan pekerjaan yang harus dilaksanakan oleh kelompok atau individu untuk mencapai tujuan yang digariskan. Lebih lanjut, Syafarudin dan Irawan menjelaskan bahwa perencanaan pembelajaran adalah salah satu fungsi awal bagi aktivitas manajemen dalam mencapai tujuan secara efektif dan efisien (Syafaruddin dan Irawan 2005: 91).

Clark \& Yinger dalam Alben Ambarita (2006: 75), menjelaskan beberapa faktor yang menjadi perhatian untuk membuat perencanaan pembelajaran yaitu: isi pembelajaran, alat-alat pembelajaran, strategi perencanaan, perilaku guru, struktur pelajaran, peningkatan pembelajaran, peserta didik, waktu yang diperlukan dalam belajar, dan tempat belajar. Sementara itu, dalam Permendiknas nomor 41 tahun 2007 tentang perencanaan pembelajaran meliputi penyusunan silabus dan rencana pelaksanaan pembelajaran (RPP) yang memuat sekurang-kurangnya tujuan pembelajaran, materi bahan ajar, sumber belajar, metode pembelajaran, dan penilaian hasil belajar.

a. Tujuan pembelajaran

Menurut Permendiknas nomor 41 tahun 2007 tentang tujuan pembelajaran menggambarkan proses dan hasil belajar yang diharapkan dicapai oleh peserta didik sesuai dengan kompetensi dasar. Sementara itu, menurut Robert F. Mager dalam Hamzah B. Uno (2008: 35), tujuan pembelajaran merupakan perilaku yang hendak dicapai atau yang dapat dikerjakan siswa pada kondisi dan tingkat kompetensi tertentu. Berdasarkan uraian tersebut, tujuan pembelajaran merupakan perilaku yang dapat dikerjakan dan dicapai siswa pada tingkat kompetensi tertentu. 
b. Materi pembelajaran

Dalam Permendiknas nomor 41 tahun 2007 tentang materi ajar memuat fakta, konsep, prinsip dan prosedur yang relevan, dan ditulis dalam bentuk butir-butir sesuai dengan rumusan indikator pencapaian kompetensi. Sementara itu, Trianto (2011: 205) mengemukakan bahwa materi pembelajaran pada hakikatnya berisi butir-butir bahan pembelajaran pokok yang dibutuhkan peserta didik untuk mencapai suatu kompetensi dasar. Berdasarkan uraian tersebut, materi pembelajaran berisi butir-butir bahan pembelajaran pokok yang dibutuhkan peserta didik meliputi fakta, konsep, prinsip, dan prosedur.

c. Sumber belajar

Dalam Permendiknas nomor 41 tahun 2007 tentang penentuan sumber belajar didasarkan pada standar kompetensi dan kompetensi dasar, serta materi ajar, kegiatan pembelajaran, dan indikator pencapaian kompetensi. Lebih lanjut, Mulyasa (2014: 56) menjelaskan bahwa sumber belajar dapat dirumuskan sebagai segala sesuatu yang dapat memberikan kemudahan belajar, sehingga diperoleh sejumlah informasi. Dengan demikian sumber belajar merupakan segala sesuatu yang bisa memberikan kemudahan belajar siswa untuk mencapai standar kompetensi dan kompetensi dasar.

d. Metode pembelajaran

Dalam Permendiknas nomor 41 tahun 2007, dijelaskan bahwa metode pembelajaran digunakan oleh guru untuk mewujudkan suasana belajar dan proses pembelajaran agar peserta didik mencapai kompetensi dasar. Lebih lanjut, Hamzah B. Uno (2008: 16) menjelaskan bahwa metode pembelajaran merupakan cara-cara yang berbeda untuk mencapai hasil pembelajaran yang berbeda di bawah kondisi yang berbeda. Berdasarkan uraian tersebut, metode pembelajaran merupakan cara yang digunakan guru untuk mewujudkan proses pembelajaran yang baik agar peserta didik dapat mencapai kompetensi dasar.

e. Kegiatan pembelajaran

Dalam Permendiknas nomor 41 tahun 2007, dijelaskan bahwa kegiatan pembelajaran meliputi kegiatan pendahuluan, kegiatan inti, dan kegiatan penutup. Sejalan dengan pendapat tersebut, Rusman juga mengungkapkan bahwa di dalam kegiatan pembelajaran terdapat tiga kegiatan, yaitu kegiatan pendahuluan, kegiatan inti, dan kegiatan penutup. Jadi, dapat disimpulkan bahwa dalam kegiatan pembelajaran terdiri dari kegiatan pendahuluan, kegiatan inti, dan kegiatan penutup (Rusman, 2012: 87).

f. Penilaian hasil belajar

Dalam Permendiknas nomor 41 tahun 2007, dijelaskan bahwa prosedur dan instrumen penilaian proses dan hasil belajar disesuaikan dengan indikator pencapaian kompetensi dan mengacu kepada standar penilaian. Sementara itu, Rusman (2012: 69) menjelaskan bahwa penilaian bermaksud untuk mengetahui kelebihan dan kelemahan, sehingga dapat ditindak lanjuti menuju perbaikan dimasa yang akan datang. Dengan demikian, penilaian hasil belajar merupakan suatu cara untuk mengetahui kelebihan dan kelemahan sehingga dapat diperbaiki.

Dari uraian di atas, dapat disimpulkan bahwa perencanaan pembelajaran adalah suatu kegiatan yang dilakukan oleh guru yaitu menetapkan rangkaian tindakan kedepan untuk menjelaskan gambaran dan langkah-langkah proses pembelajaran yang akan datang dengan tujuan agar pelaksanakaan pembelajaran berjalan dengan baik, efektif, dan efisien. Perencanaan pembelajaran mencakup kegiatan-kegiatan merencanakan tujuan pembelajaran, materi pembelajaran, sumber belajar, metode pembelajaran, serta 
kegiatan pembelajaran yang dilakukan oleh guru.

Dengan demikian, supervisi akademik oleh kepala sekolah pada perencanaan pembelajaran dapat dilakukan dengan memberikan bimbingan dalam merumuskan tujuan pembelajaran, arahan dalam memilih materi pembelajaran, bimbingan dalam mengorganisir materi pembelajaran, arahan dalam memilih metode pembelajaran, arahan dalam memilih sumber belajar/media pembelajaran, dan bimbingan dalam menskenario/kegiatan pembelajaran.

\subsubsection{Supervisi Akademik pada Pelaksanaan Pembelajaran}

Pelaksanaan pembelajaran merupakan inti dari kegiatan pendidikan di sekolah. Menurut B. Suryosubroto (2002: 36), pelaksanaan pembelajaran merupakan terjadinya interaksi guru dengan siswa dalam rangka menyampaikan bahan pelajaran kepada siswa untuk mencapai tujuan pengajaran. Sejalan dengan pendapat tersebut, Abdul Majid (2006: 111) mengemukakan bahwa pelaksanaan pembelajaran merupakan suatu proses penyelenggaraan interaksi peserta didik dengan pendidik dan sumber belajar pada suatu lingkungan belajar.

Pelaksanaan proses pembelajaran, menurut B. Suryosubroto (2002: 27) meliputi kegiatan membuka pembelajaran, melaksanakan inti proses pembelajaran, dan menutup pembelajaran. Lebih lanjut, Rusman (2014: 10) menguraikan bahwa pelaksanaan pembelajaran meliputi:

a. Kegiatan pendahuluan: menyiapkan peserta didik, mengajukan pertanyaan, menjelaskan tujuan, menyampaikan cakupan materi,

b. Kegiatan inti: proses pembelajaran untuk mencapai kompetensi dasar yang dilakukan secara interaktif, inspiratif, menyenangkan, menantang, memotivasi, serta memberikan ruangan yang cukup bagi prakarsa, kreativitas, dan kemandirian sesuai bakat dan minat,

c. Kegiatan penutup: bersama-sama membuat kesimpulan pelajaran, melakukan refleksi, memberikan umpan balik, merencanakan tindak lanjut, menyampaikan rencana pembelajaran pada pertemuan berikutnya.

Berdasarkan uraian di atas, dapat diambil kesimpulan bahwa pelaksanaan pembelajaran merupakan suatu proses terjadinya interaksi guru dengan siswa dalam rangka menyampaikan bahan pelajaran kepada siswa pada suatu lingkungan belajar. Kegiatan-kegiatan dalam pelaksanaan pembelajaran yaitu kegiatan membuka pembelajaran, kegiatan inti pembelajaran, dan kegiatan menutup pembelajaran

Dengan demikian, supervisi akademik oleh kepala sekolah pada pelaksanaan pembelajaran dapat dilakukan dengan memberikan contoh dalam membuka pembelajaran, memberikan contoh dalam menyajikan materi pembelajaran, arahan dalam menggunakan metode pembelajaran, bimbingan dalam memanfaatkan media pembelajaran, bimbingan dalam menggunakan bahasa komunikatif, bantuan dalam memotivasi siswa, bimbingan dalam mengorganisasi kegiatan pembelajaran, memberikan contoh dalam berinteraksi dengan siswa, memberikan contoh dalam menyimpulkan pembelajaran, memberikan contoh dalam pemberian umpan balik pada siswa, arahan dalam menggunakan waktu yang efektif, dan memberikan contoh dalam menutup kegiatan pembelajaran. 


\subsubsection{Supervisi Akademik pada Evaluasi Pembelajaran}

Evaluasi atau penilaian hasil belajar bertujuan untuk melihat kemajuan belajar siswa dalam hal penguasaan materi pelajaran yang telah dipelajari. Menurut Abdul Majid (2004: 193), penilaian harus digunakan sebagai proses untuk mengukur dan menentukan tingkat ketercapaian kompetensi dan sekaligus untuk mengukur efektifitas proses pembelajaran. Dengan demikian, evaluasi atau penilaian pembelajaran sangat diperlukan dalam proses pembelajaran.

Undang-undang Republik Indonesia nomor 20 tahun 2003 Bab XVI pasal 57 ayat 1 dan pasal 58 ayat 8 menyatakan bahwa, "Evaluasi dilakukan dalam rangka pengendalian mutu pendidikan secara nasional sebagai bentuk akuntabilitas penyelenggaraan pendidikan kepada pihak-pihak yang berkepentingan. Evaluasi belajar peserta didik dilakukan oleh pendidik untuk memantau proses, kemajuan, dan perbaikan hasil belajar secara berkesinambungan". Dengan demikian, evaluasi terhadap hasil belajar yang telah menjadi standar keberhasilan perlu dilakukan oleh guru. Sementara itu, Abdul Majid (2006: 224) menyatakan bahwa evaluasi terhadap hasil belajar bertujuan untuk mengetahui ketuntasan siswa dalam menguasai kompetensi dasar. Dari hasil evaluasi tersebut dapat diketahui kompetensi dasar, materi, atau indikator yang belum mencapai ketuntasan.

Berdasarkan uraian tersebut, maka dapat dilihat bahwa penilaian pembelajaran mempunyai manfaat yang sangat besar, sebab dengan adanya evaluasi atau penilaian maka perkembangan kecerdasan siswa selama mengikuti proses pembelajaran dapat diukur. Dalam Permendiknas RI nomor 20 tahun 2007, dijelaskan bahwa penilaian hasil belajar bertujuan untuk memantau proses dan kemajuan belajar peserta didik serta untuk meningkatkan efektivitas kegiatan pembelajaran.

Dengan demikian, supervisi akademik oleh kepala sekolah pada evaluasi pembelajaran dapat dilakukan dengan memberikan bimbingan dalam menyusun perangkat penilaian pembelajaran, bimbingan dalam membuat soal-soal pembelajaran, arahan dalam menggunakan strategi dan metode penilaian pembelajaran, arahan dalam memeriksa jawaban penilaian belajar siswa, bimbingan dalam mengolah dan menganalisis hasil penilaian belajar siswa, dan bimbingan dalam memanfaatkan hasil penilaian belajar siswa.

Berdasarkan beberapa penjelasan di atas, maka dapat disintesiskan bahwa supervisi akademik kepala sekolah merupakan pemberian bimbingan dalam menyusun perangkat pembelajaran, bimbingan dan arahan kepada guru guna ketercapaian hasil belajar siswa yang maksimal.

\section{Supervisi Akademik Kepala Sekolah dan Kinerja Guru 4.1. Pelaksanaan Supervisi Akademik Kepala Sekolah}

\subsubsection{Supervisi Akademik pada Perencanaan Pembelajaran}

Supervisi akademik pada perencanaan pembelajaran oleh kepala sekolah terdiri dari pembimbingan dalam merumuskan tujuan pembelajaran, pengarahan dalam memilih materi pembelajaran, pembimbingan dalam mengorganisir materi pembelajaran, pengarahan dalam memilih metode pembelajaran, pengarahan dalam memilih sumber belajar/media pembelajaran, dan pembimbingan dalam menskenario kegiatan pembelajaran. Hasil penelitian menunjukkan bahwa supervisi akademik oleh kepala sekolah pada perencanaan pembelajaran yang termasuk dalam kategori baik, yaitu pembimbingan dalam merumuskan tujuan pembelajaran.

Berdasarkan hasil wawancara dengan kepala SDN 79 Kota Bengkulu, diperoleh 
informasi bahwa dalam melakukan bimbingan pada perencanaan pembelajaran, kepala sekolah selalu mengecek dan melihat administrasi perangkat perencanaan pembelajaran yang dibuat oleh guru. Pada perencanaan pembelajaran kepala sekolah tidak melakukan bimbingan secara langsung kepada guru dalam hal pembuatan silabus dan RPP. Kepala sekolah cenderung melakukan bimbingan dengan cara mengadakan workshop dengan menghadirkan pembicara dari praktisi pendidikan. Dalam acara itu para guru mendapat bantuan dan pelatihan dari narasumber profesional mengenai bagaimana merencanakan pembelajaran yang baik, terutama dalam penyusunan dan pengembangan silabus serta RPP.

Berdasarkan hasil wawancara dengan beberapa kepala SDN 179 Kabupaten Seluma, diperoleh informasi bahwa dalam melakukan bimbingan pada perencanaan pembelajaran, kepala sekolah lebih banyak memberikan arahan dan masukan terkait dengan pembuatan RPP dan silabus yang dibuat oleh guru. Kepala sekolah juga memberikan saran-saran pada guru dalam hal memilih materi, metode, dan sumber belajar yang sesuai dengan siswa. Dengan demikian, para guru diharapkan dapat melaksanakan pembelajaran secara baik dengan berpedoman pada rencana pembelajaran yang telah dibuat oleh masing-masing guru.

Kegiatan supervisi akademik oleh kepala sekolah dengan cara mengadakan workshop dan tidak melakukan bimbingan langsung kepada guru dalam merencanakan pembelajaran tersebut dianggap oleh para guru sebagai supervisi akademik yang kurang baik. Seperti ditegaskan Direktorat Tenaga Kependidikan Kemendikbud, kepala sekolah berkewajiban membimbing guru dalam menyusun silabus dan rencana pelaksanaan pembelajaran (RPP) untuk tiap mata pelajaran dalam rumpun mata pelajaran yang relevan di sekolah menengah yang sejenis (Departemen Pendidikan Nasional, 2010: 5).

Selain itu, dijelaskan pula bahwa kepala sekolah harus membimbing guru dalam memilih dan menggunakan strategi/metode/teknik pembelajaran/bimbingan yang dapat mengembangkan berbagai potensi siswa melalui mata-mata pelajaran dalam rumpun mata pelajaran yang relevan di sekolah. Maka dari itu, dalam hal merencanakan pembelajaran seharusnya kepala sekolah melakukan bimbingan secara langsung kepada guru dengan cara memberikan masukan serta arahan-arahan dalam hal pemilihan dan penggunaan materi, metode, dan sumber pembelajaran yang tepat agar dapat mengembangkan berbagai potensi siswa.

\subsubsection{Supervisi Akademik pada Pelaksanaan Pembelajaran}

Supervisi akademik pada pelaksanaan pembelajaran, meliputi: pemberian contoh dalam membuka pembelajaran, pemberian contoh dalam menyajikan materi pembelajaran, pengarahan dalam menggunakan metode pembelajaran, pembimbingan dalam memanfaatkan media pembelajaran, pembimbingan dalam menggunakan bahasa komunikatif, bantuan dalam memotivasi siswa, pembimbingan dalam mengorganisasi kegiatan pembelajaran, pemberian contoh dalam berinteraksi dengan siswa, pemberian contoh dalam menyimpulkan pembelajaran, pemberian contoh dalam memberikan umpan balik pada siswa, pengarahan dalam menggunakan waktu yang efektif, dan pemberian contoh dalam menutup kegiatan pembelajaran.

Berdasarkan hasil wawancara dengan kepala SDN 79 Kota Bengkulu, diperoleh informasi bahwa dalam melakukan bimbingan pada saat guru melaksanakan pembelajaran, kepala sekolah biasanya melakukan kunjungan kelas. Dengan kunjungan kelas tersebut kepala sekolah dapat melihat dan memastikan apakah para guru melaksanakan pembelajaran dengan baik atau tidak. Selain itu, kepala sekolah juga 
sering membantu guru apabila ada yang mengalami kesulitan pada saat melaksanakan kegiatan pembelajaran. Bantuan dari kepala sekolah tersebut dilakukan dengan memberikan arahan-arahan pada guru agar dapat melaksanakan dengan baik dan lancar.

Menurut Direktorat Tenaga Kependidikan Kemendikbud, ditegaskan bahwa kepala sekolah harus membimbing guru dalam melaksanakan kegiatan pembelajaran/bimbingan (di kelas/laboratorium, dan atau dilapangan) untuk tiap mata pelajaran dalam rumpun mata pelajaran yang relevan di sekolah menengah yang sejenis. Kegiatan supervisi akademik oleh kepala sekolah dengan cara kunjungan kelas yang sebatas hanya dengan melihat serta memastikan pelaksanaan pembelajaran berjalan dengan baik tersebut dianggap oleh para guru sebagai supervisi akademik yang kurang baik. Kegiatan supervisi akademik oleh kepala sekolah pada pelaksanaan pembelajaran seharusnya dilakukan dengan cara demonstrasi mengajar agar dapat memberikan manfaat secara langsung bagi guru.

Hal ini sesuai dengan pendapat Pupuh Fathurrohman dan Aa Suryana (2011: 206), yang menyebutkan bahwa salah satu teknik supervisi profesional yang dapat memberikan manfaat langsung bagi peningkatan kemampuan mengajar guru-guru adalah demonstrasi mengajar. Maka dari itu, kepala sekolah perlu melakukan demonstrasi mengajar karena melalui demonstrasi mengajar guru-guru dapat mengamati langsung cara-cara mengajar yang baik sehingga para guru dapat mempraktikkannya kembali pada siswanya.

Berdasarkan hasil wawancara dengan kepala SDN 79 Kota Bengkulu, diperoleh informasi bahwa dalam melakukan bimbingan pada saat guru melaksanakan pembelajaran, kepala sekolah mengajarkan pada guru untuk memanfaatkan media pembelajaran atau alat-alat praktik yang tersedia agar digunakan oleh guru sebagai sarana dalam melakukan kegiatan pembelajaran. Selain itu, kepala sekolah juga mengajarkan pada guru cara-cara berinteraksi dengan siswa yang komunikatif agar siswa dapat tertarik dan antusias, sehingga materi pelajaran benar-benar dapat tersampaikan pada siswa.

Bimbingan dari kepala sekolah dengan cara mengajarkan pada guru untuk memanfaatkan media pembelajaran serta cara berinteraksi dengan siswa secara komunikatif tersebut dianggap oleh para guru sebagai supervisi akademik yang baik. Guru-guru merasa lebih terbantu dengan adanya supervisi akademik oleh kepala sekolah dengan cara tersebut, sehingga mereka akan dapat melaksanakan kegiatan pembelajaran dengan baik.

\subsubsection{Supervisi Akademik pada Evaluasi Pembelajaran}

Supervisi akademik pada evaluasi pembelajaran, meliputi: pembimbingan dalam menyusun perangkat penilaian pembelajaran, pembimbingan dalam membuat soal-soal pembelajaran, pengarahan dalam menggunakan strategi dan metode penilaian pembelajaran, pengarahan dalam memeriksa jawaban penilaian belajar siswa, pembimbingan dalam mengolah dan menganalisis hasil penilaian belajar siswa, dan pembimbingan dalam memanfaatkan hasil penilaian belajar siswa.

Berdasarkan hasil wawancara dengan kepala SDN 79 Kota Bengkulu, diperoleh informasi bahwa dalam melakukan bimbingan pada evaluasi pembelajaran, kepala sekolah selalu mengecek dan memberi masukan mengenai perangkat penilaian yang dipersiapkan guru. Bimbingan yang sifatnya langsung dari kepala sekolah menyangkut evaluasi pembelajaran, dilakukan dengan menanyakan pada guru tentang proses evalusi pembelajaran yang telah dilaksanakannya. Apabila ada guru yang mengalami kesulitan 
atau masalah dalam melaksanakan evaluasi pembelajaran, maka kepala sekolah akan berusaha untuk membantu mengatasi permasalahan yang dihadapi guru tersebut.

Berdasarkan hasil wawancara dengan kepala SDN 79 Kota Bengkulu, diperoleh informasi bahwa dalam melakukan bimbingan pada evaluasi pembelajaran, kepala sekolah selalu mengoreksi dan memberikan masukan tentang instrumen penilaian yang dipersiapkan guru untuk mengevaluasi pembelajaran siswa. Selain itu, kepala sekolah juga mengarahkan guru-guru untuk dapat melakukan penilaian pembelajaran dengan benar. Hal tersebut bertujuan supaya pelaksanaan evaluasi pembelajaran benar-benar dapat mengukur dan melihat kemajuan belajar siswa dalam hal penguasaan materi pembelajaran yang telah dipelajari.

Dalam Permendiknas RI nomor 20 tahun 2007 tentang penilaian hasil belajar bertujuan untuk memantau proses dan kemajuan belajar peserta didik serta untuk meningkatkan efektivitas kegiatan pembelajaran. Dengan demikian, kepala sekolah berkewajiban membimbing guru dalam hal menilai hasil belajar siswa agar pelaksanaan evaluasi pembelajaran yang dilakukan benar-benar dapat mengukur dan melihat kemajuan belajar siswa. Kegiatan supervisi akademik oleh kepala sekolah dalam hal evaluasi pembelajaran yang hanya dilakukan dengan mengecek perangkat penilaian yang dipersiapkan guru tersebut, dianggap oleh para guru sebagai supervisi akademik yang kurang baik.

Menurut Ngalim Purwanto, disebutkan bahwa sebagai supervisor, kepala sekolah berkewajiban membantu mengelola pembelajaran di kelas dan membantu guru dalam menilai proses pembelajaran yaitu bagaimana menggunakan teknik-teknik evaluasi dan pelaksanaan evaluasi itu sendiri. Dengan demikian, dalam kegiatan evaluasi pembelajaran kepala sekolah seharusnya membimbing guru dalam hal pembuatan soal-soal pembelajaran, penggunaan strategi dan metode penilaian, serta mengolah dan menganalisis hasil pembelajaran siswa supaya dapat mengukur dan melihat kemajuan belajar siswa.

Arahan dari kepala sekolah untuk melakukan evaluasi pembelajaran dengan benar serta pemberian masukan-masukan mengenai instrumen penilaian yang dipersiapkan guru tersebut dianggap oleh guru sebagai kegiatan supervisi akademik yang baik. Dengan adanya masukan-masukan dari kepala sekolah tersebut membuat para guru merasa lebih terbantu dalam melaksanakan tugasnya yaitu mengevaluasi pembelajaran siswa.

\subsection{Hasil Supervisi Akademik terhadap Kinerja Guru PAI}

\subsubsection{Perencanaan Pembelajaran}

Berdasarkan hasil penelitian, bahwa guru Pendidikan Agama Islam, selalu mempersiapkan silabus pembelajaran sebagai bahan acuan dalam menganalisa materi pelajaran serta dalam membuat rencana program pembelajaran. Silabus pembelajaran dicantumkan; standar kompetensi dan kompetensi dasar, struktur keilmuan, kedalam materi, relevansi dan alokasi waktu. Dengan demikian, dapat diketahui bahwa guru pendidikan agama Islam dalam menganalisa materi pelajaran menyesuaikan dengan yang ada di silabus. Hal ini menunjukkan guru pendidikan agama Islam dapat memahami persiapan perangkat pembelajaran yang harus dipersiapkan dalam mengajar.

Hasil penilitian penulis di lapangan, ketika guru pendidikan agama Islam di SD Negeri 79 Kota Bengkulu menyampaikan materi pelajaran, ia dapat menyampaikannya dengan baik tanpa ada kesulitan dari segi materi, sehingga materi yang disampaikan dapat berlangsung dengan lancar. 
Program pembelajaran yang telah direncanakan dapat dikelola dengan baik. Hal ini dibuktikan perangkat pembelajaran tersusun dan terorganisasi dengan benar serta terlaksana sesuai dengan program yang direncanakan. Di samping itu, guru PAI diketahui bahwa, program pembelajaran yang telah dipersiapkan dapat dilaksanakan sesuai dengan rencana, seperti Rencana Program Pembelajaran (RPP) yang telah dibuat, dan dijadikan sebagai acuan dalam pembelajaran. Dari wawancara guru PAI diketahui bahwa program pembelajaran terkelola dengan tepat, yaitu mulai dari penentuan tujuan sampai dengan pelaksanaan evaluasi.

Hasil temuan di lapangan, bahwa guru pendidikan agama Islam di SD Negeri 79 Kota Bengkulu menciptakan suasana kelas agar tetap tenang, dengan cara dengan mengkondisikan atau menguasai kelas/ menguasai kondisi kelas dan bisa memahami situasi siswa. Cara menciptakan suasana belajar yang tidak membosankan dan agar terciptakan suasana belajar yang tidak membosankan bagi siswa, maka harus melibatkan siswa untuk selalu aktif.

Berdasarkan hasil temuan di lapangan, Sumber belajar yang dikembangkan guru sudah memenuhi kebutuhan belajar siswa, seperti buku materi pelajaran yang berkaitan dengan sejarah Islam, di samping itu materi tersebut menggunakan audiovisual, dimana siswa disuruh menyaksikan sejarah peristiwa masa keemasan Islam. Dengan demikian, sumber belajar yang digunakan guru dalam menyampaikan mata pelajaran PAI di SD Negeri 79 Kota Bengkulu telah memenuhi kebutuhan siswa.

Kompetensi guru mengembangkan jenis penilaian terhadap hasil belajar siswa, bahwa jenis penilaiannya sesuai dengan materi, contoh Al-Qur'an dengan jenis penilaian praktek membaca, dan shalat dengan jenis penilaian praktek mengerjakan shalat. Jenis penilaian terhadap hasil belajar siswa pada mata pelajaran Pendidikan Agama Islam di SD Negeri 79 Kota Bengkulu disesuaikan dengan materi pelajaran yang disampaikan, sehingga dapat mewujudkan penilaian secara optimal.

Selain itu, penilaian indikator keberhasilan belajar siswa pada mata pelajaran Pendidikan Agama Islam di SD Negeri 79 Kota Bengkulu telah disesuaikan dengan materi yang disampaikan dan kemampuan siswa. Karena bila tidak, maka keberhasilan dan ketuntasan belajar tidak akan tercapai dengan baik. Dengan adanya penentuan sumber belajar dan jenis penilaian/evaluasi di SD Negeri 79 Kota Bengkulu, berarti telah mengimplementasikan Peraturan Pemerintah Nomor 19 Tahun 2005 tentang Standar Nasional Pendidikan, yang di antaranya adalah tentang sarana dan prasarana, serta penilaian pendidikan.

\subsection{Faktor-Faktor yang Mempengaruhi Pelaksanaan Supervisi Akademik}

Keberhasilan pelaksanaan supervisi kepala sekolah dipengaruhi oleh beberapa faktor pendukungnya, yakni guru yang menjadi sasaran supervisi kepala sekolah bersikap koperatif dan terbuka terhadap proses supervisi yang dilakukan oleh pengawas, bahkan mereka merasa ingin dan senang jika supervisi dilakukan dalam meningkatkan kualitas kinerja mereka.

Selanjutnya, yang menjadi pendukung yaitu keberadaan pengawas mata pelajaran Pendidikan Agama Islam di SDN 79 Kota Bengkulu menjadi faktor pendukung keberhasilan supervisi kepala sekolah. Pengawas mata pelajaran Pendidikan Agama Islam di SDN 79 Kota Bengkulu merupakan Pengawas senior yang telah berpengalaman dengan masa kerja enam sampai sepuluh tahun sebagai pengawas dengan latar belakang sebagai guru dan kepala madrasah. Pengawas tersebut telah 
mengukuti berbagai pendidikan dan latihan, penataran, workshop, orientasi, dan kegiatan sejenis lainnya.

Adapun faktor penghambat pelaksanaan supervisi kepala sekolah dalam upaya peningkatan kinerja guru Pendidikan Agama Islam, adanya permasalahan yang muncul pada pembelajaran Pendidikan agama Islam di SD Negeri 79 Kota Bengkulu adalah sempitnya alokasi waktu untuk pelaksanaan pembelajaran PAI di sekolah dasar, yang hanya diberi alokasi waktiu 1 jam pelajaran (35 menit) untuk setiap minggunya, serta sebagian besar guru SD kurang begitu mampu menguasai materi Pendidikan Agama Islam yang bersifat hafalan dan membutuhkan wawasan yang sangat luas serta berubah setiap waktu.

Sebagai akibat dari kurangnya perhatian terhadap mata pelajaran Pendidikan Agama Islam ini, maka banyak dari para siswa yang mendapatkan hasil kurang memuaskan dalam setiap evaluasi, sehingga pelajaran PAI dianggap sangat sulit dan membingungkan. Untuk mengatasi kesulitan pembelajaran Pendidikan Agama Islam ini dipandang perlu menggunakan perbaikan pembelajaran kepada para guru dalam meningkatkan kinerja guru pada pembelajaran Pendidikan Agama Islam dengan menggunakan supervisi kepala sekolah, guna mendapatkan pembelajaran yang lebih berkualitas di sekolah. Disamping itu, kendala yang dihadapi dalam peningkatan dan pengembangan kemampuan profesionalisme mengajar guru di sekolah yaitu lemahnya motivasi yang dimiliki oleh pihak guru dalam mengadakan peningkatan kemampuan profesionalnya. Lemahnya motivasi dalam meningkatkan kemampuan mereka beralasan karena sibuknya waktu dalam melakukan pengajaran.

Kendala lain yang dihadapi oleh kepala sekolah dalam melakukan peningkatan kinerja guru di sekolah adalah kurangnya sarana dan prasarana peningkatan kinerja guru. Selama ini kegiatan peningkatan yang dilakukan kepala sekolah adalah melalui prosedur yang sederhana dan sarana maupun prasarana yang terbatas. Peningkatan ini memerlukan sarana dan prasarana yang memadai, sehingga dalam pelaksanaannya mampu diwujudkan sesuai dengan tujuan yang diharapkan. Sarana dan prasarana tersebut akan mempengaruhi hasil peningkatan, dikarenakan kepala sekolah merasa kesulitan untuk melakukan peningkatan.

Dengan demikian secara keseluruhan bahwa peningkatan kinerja guru dapat dilakukan dengan sebaik-baiknya oleh kepala sekolah. Permasalahan-permasalahan yang ditemui pada saat peningkatan kinerja guru yang dilakukan kepala sekolah pada dasarnya tidak begitu mengganggu terhadap jalannya program peningkatan apabila penanganannya dilakukan dengan baik. Tentunya kepala sekolah memerlukan kesiapan mental dan kemampuan dalam menangani permasalahan yang ada, sehingga tetap pelaksanaan program peningkatan berjalan dengan baik.

Dalam menghadapi permasalahan itu juga, kepala sekolah diharapkan lebih optimal melaksanakan kegiatan peningkatan sesuai dengan program dan prosedur yang telah ditetapkan, sehingga permasalahan dapat diatasi dengan baik dan lancar oleh guru Pendidikan Agama Islam. Dengan demikian, inilah yang penulis sebut sebagai paradigma lama pendidikan di Indonesia. Kalau demikian halnya maka supervisi kepala sekolah akan terhambat karena inti dari tujuan supervisi adalah peningkatan kinerja dan kualitas proses pembelajaran yang pada akhirnya akan meningkatkan kualitas hasil pembelajaran.

Penghambat yang adalah rendahnya pengembangan kualitas diri guru menjadi penyebab yang dapat lambatnya keberhasilan supervisi kepala sekolah SD Negeri 79 Kota Bengkulu. Selain itu, lemahnya perhatian guru terhadap kelengkapan perangkat 
pembelajaran, kondisi guru dalam kaitan dengan kelengkapan perangkat pembelajaran adalah sebagai berikut: tidak banyak guru yang kelengkapan perangkat pembelajarannya atas hasil karyanya sendiri. Jika guru telah mempunyai kelengkapan perangkat pembelajaran, pada umumnya enggan membawa perangkat tersebut kedalam kelas ketika melaksanakan proses pembelajaran.

\section{Kesimpulan}

Pertama, Supervisi akademik yang dilaksanakan oleh kepala sekolah dalam peningkatan kinerja guru PAI, yaitu: 1) supervisi akademik berkaitan dengan perencanaan pembelajaran terdiri dari pembimbingan dalam merumuskan tujuan pembelajaran, pemilihan materi pembelajaran, metode dan media pembelajaran. 2) supervisi akademik pada pelaksanaan pembelajaran, meliputi: pemberian contoh dalam membuka pembelajaran, pemberian contoh dalam menyajikan materi pembelajaran, pengarahan dalam menggunakan metode dan pemanfaatan media pembelajaran. 3) supervisi akademik pada evaluasi pembelajaran, meliputi: pembimbingan dalam menyusun perangkat penilaian pembelajaran, membuat soal-soal pembelajaran, menggunakan strategi dan metode penilaian pembelajaran, dan memeriksa jawaban penilaian belajar siswa.

Kedua, Faktor-faktor yang mempengaruhi pelaksanaan supervisi akademik, yaitu: 1) Faktor pendukungnya, yakni guru yang menjadi sasaran supervisi kepala sekolah bersikap koperatif dan terbuka terhadap proses supervisi yang dilakukan oleh pengawas, bahkan mereka merasa ingin dan senang jika supervisi dilakukan dalam meningkatkan kualitas kinerja mereka. 2) Faktor penghambat pelaksanaan supervisi kepala sekolah dalam upaya peningkatan kinerja guru Pendidikan Agama Islam, adanya permasalahan yang muncul pada pembelajaran Pendidikan agama Islam adalah sempitnya alokasi waktu untuk pelaksanaan pembelajaran PAI di sekolah dasar.

\section{Daftar Pustaka}

Ambarita, A. (2006). Manajemen Pembelajaran. Jakarta: Rineka Cipta.

Arikunto, S. (2009). Dasar-Dasar Supervisi. Jakarta: PT. Rineka Cipta. . (2010). Prosedur Penelitian Suatu Pendekatan Praktik Edisi Revisi ke VI. Jakarta: Rineka Cipta.

Departemen Pendidikan Nasional. (2007). Pendidikan dan Pelatihan: Supervisi Akademik dalam Peningkatan Profesionalisme Guru. Jakarta: Kemendikbud.

Komaruddin \& Yooke. T. (2000). Kamus Istilah Karya Tulis Ilmiah, Jakarta: Bumi Aksara.

Majid, A. (2006). Perencanaan Pembelajaran. Bandung: PT Remaja Rosdakarya.

Mukhtar \& Iskandar. (2009). Orientasi Baru Supervisi Pendidikan. Jakarta: Gaung Persada.

Mulyasa, E. (2014). Menjadi Kepala Sekolah Profesional. Bandung: PT. Remaja Rosdakarya. 
(2008). Standar Kompetensi dan Sertifikasi Guru. Bandung: Rosdakarya.

Prasojo, L. D., \& Sudiyono. (2011). Supervisi Pendidikan. Yogyakarta: Gava Media.

Purwanto, N. (2010). Administrasi dan Supervisi Pendidikan. Bandung: Remaja Rosdakarya Offset.

Rusman. (2012). Model-model Pembelajaran: Mengembangkan Profesionalisme Guru. Jakarta: Rajawali Pers.

Satori, D. (2014). Paradigma Baru Supervisi Pendidikan untuk Peningkatan Mutu dalam Konteks Peranan Pengawas Sekolah dalam Otonomi Daerah. Bandung: APSI Provinsi Jawa Barat.

Sugiyono. (2008). Metode Penelitian Pendidikan, Pendekatan Kuantitatif, Kualitatif, dan $R \& D$. Bandung: Alfabeta.

Suryosubroto, B. (2012). Proses Pembelajaran di Sekolah. Jakarta: PT Rineka Cipta.

Syafaruddin \& Irawan, N. (2005). Manajemen Pembelajaran. Jakarta: Ciputat Press.

Sagala, S. (2009). Kemampuan Profesional Guru dan Tenaga Kependidikan. Bandung: Alfabeta.

Trianto, (2011). Mendesain Model Pembelajaran Inovatif-Progresif. Jakarta: Kencana.

Uno, H. B. U., (2008). Perencanaan Pembelajaran. Jakarta: Bumi Aksara. 